\title{
The Semiotic Method of Cognition of Reality: Limits of Applicability
}

\author{
Platon A. Kuzmin \\ Graduate School of the Moscow Theological Academy \\ Academy, The territory of the Lavra, Sergiev Posad, Moscow Region, Russia, 141300
}

\begin{abstract}
This article discusses the degree and usefulness of the applicability of the semiotic method in science, philosophy and academic theology. The philosophy of the semiotic method and its relationship with Orthodox theology are considered. A specific case of application of the semiotic method in Russian science in the study of theological texts in the works of S.S. Averintsev is presented and studied. It is concluded that the extensional universality of the semiotic method in all spheres of knowledge and its limitations in the ability to adequately reflect reality.
\end{abstract}

Key words: semiotic method, semiotics, sign, reality, theology

\section{Introduction}

Semiotics is a relatively young science, but it already claims to be universal. What are the limits of the semiotic method?

Relevance: A person, being in a society, at the same time is in a particular cultural environment, which is created by verbal or non-verbal language. Russian or English, as well as the style of clothing, fashion, cultural traditions, works of art - is the language, that is a set of signs that a person uses to express themselves and interacts with other people, their identification and understanding. Philosophy, science and religion also use their language to describe reality. A person perceives much through signs. Prof. T.V. Chernigovskaya once said in her lecture: "People are such creatures who like to deal with virtual reality very much, they deal with signs. Well, let's say, here is a glass of water, here it is. It is already, a real glass, there is water in it. Why should we draw it? Where did the idea of duplicating the world come from? All art, as well as not art, is language, it duplicates a real glass" [1].

Modern use of PR-technologies, information wars, the activities of the media are carried out precisely with the help of signs and because a person, if you say theological language, as a verbal creature, has a natural need to use them and cannot live like a person without them. The word is also a sign. As the science semiotics that studies signs appeared relatively recently, it is important to ask the question how adequately the used sign reflects reality and what are the limits of using the semiotic method during searching

\section{Kuzmin P.A., 2019.}

(i) This work is licensed under a Creative Commons Attribution 4.0 International License https://creativecommons.org/licenses/by/4.0/ 
for an answer to this question? And can within these borders semiotics be a common language for all spheres of human activity, thereby ensuring successful dialogue and understanding?

The object of this study is the concept and essence of the semiotic method. The subject of this work will be the limits of the application of this method in science, philosophy and academic theology.

Thesis: the semiotic method can be effectively applied to the study of cultural phenomena and more generally, reality in general, but, nevertheless, has its own natural limits. A sign is effective when it refers to a real object, and not to itself or another sign. From the point of view of Orthodox theology, signs arising in the created world are limited and cannot give complete knowledge of God, but only a certain idea of Him.

The purpose of this article is to define the concept of the semiotic method and clarify its applicability in the mentioned areas.

To do this, you will need to perform the following tasks:

- to analyze the existing definitions of this method;

- to consider the history of the emergence of this concept and briefly identify the main stages of the emergence of semiotics;

- to consider the philosophical foundations of the semiotic method;

- to review some cases of application of this method in philosophy, science and theology and to analyze them;

- to summarize the information and make a conclusion.

\section{Definition of the Semiotic Method and History of the Term}

The semiotic method can be defined as a way of describing certain texts, cultural phenomena, or, more generally, reality in the form of sign systems. At the same time, the interest of the researcher is directed directly to the object, which is indicated by the sign, as a result, the scientist will make his judgment about the object, but based on the data that he will receive when studying this sign and its relationship with this object.

Trying to trace the history of the term "semiotic method", in Russian literature we find the work of Yu.M. Lotman "Analysis of the poetic text. The structure of the verse", published by "Uchpedgiz" in 1972. Yuri Mikhailovich took his "Lectures on structural poetics as a basis. Introduction. Theory of verse" 1964, which were published in a collection in Tartu [2] [16]. In the "Analysis of the poetic text" we are talking about "structural-semiotic methods", the concept of "semiotic method" is not used yet.

V.L. Bondaletov devotes Chapter in his textbook "Russian onomastics" to the concept of "semiotic method", published in 1983 in Moscow. Earlier mention of this phrase as a stable term the author did not find.

In the English literature should be mentioned the work of Sonia Maasik and Jack Solomon, entitled "The Semiotic Method", which was published in 1994 in the journal Signs of Life in the USA. 
The following definitions was given about this concept:

"The semiotic method of text analysis. Consideration of the text as a system of signs. The distinction in the framework of semiotics, semantics, syntagmatics and pragmatics of signs is significant. The semiotic method is associated with the modeling of text as a sign system. Y.M. Lotman, who developed a structural-semiotic concept, identified when he was analyzing the text:

1) functional-semantic type of speech reflected in the text;

2) the division of the text into segments and the analysis of the structure;

3) tiered detailed study of the text units;

4) analysis of rhymes;

5) generalization of observations, specification of the artistic sense" [1. P. 321-322].

"The semiotic method of cognition is a method of indirect cognition of reality, the essence of which is that the object under study, in the absence of the possibility of direct study of its research, is analyzed by its material traces, sensually perceived signs or other signs that represent it in the process of cognition. This method is based on the ability of the subject to perceive the sign and respond to it as a representative of the object of the real world.

The basic principles of the semiotic method of scientific research: the principle of objectivity (all conclusions and hypotheses arising from the analysis do not apply to the sign itself, but to the object behind it), the principle of uniqueness (prohibition of the use of the same sign to dissimilar objects and situations), the principle of interchangeability (the possibility of replacing one sign with another on the basis of their semantic identity)".

"Like information schemes, the semiotic approach makes it possible to explain and present in General the knowledge, communication and culture as a whole, "to reveal their dynamics and organization at the principal level"), operating for the time being an intuitively understood category of the sign. "For example, we do not know the actual mechanism of memory, understanding, thinking, but it is possible to intelligibly discuss these complex mental phenomena through the concept of information: memory a repository of information, understanding — decoding information, thinking — information processing" (ibid.). Add: a sign — "carrier, Keeper, broadcaster, organizer of information", meaning — "invariant of information", communicants — "transmitters and recipients of information", etc." [3. P. 86].

"The definition of the second type - the definition of the method: "Semiotics is the application of linguistic methods to objects other than natural language". What's the meaning of that? This means that semiotics is a way of treating anything as constructed and functioning like a language. In this "like" — the crux of the method. Everything can be described as a language (or as having a language): kinship system, card games, gestures and facial expressions, cooking, religious rituals and insect behavior. Semiotics, therefore, is the transfer of the metaphor of language to any non-linguistic (from the point of view of ordinary, "non-semiotic" consciousness) phenomena. One of the principles on which semiotics is based is the expansion of the meaning of linguistic terms. So the method of semiotics is to treat anything as a metaphor for language, or to put it another way, a metaphorical description of anything as language." 


\section{The Philosophy of the Semiotic Method}

Topics for philosophical understanding here are the problem of the relationship of sign and reality, indirect knowledge of reality, interpretation, meaning, the expression of abstract concepts in material forms, the influence of symbols on social life, the relationship of language and thought, the study of language as a coherent set of signs, the knowledge of truth, theuniversality of symbolism and semiotics, the boundaries of the application of the semiotic method and the conventionality of the sign.

E.A. Taysina names the following possible philosophical foundations of semiotics: dialectical materialism, essentialism, rationalism, the acceptance of the absolute truth, relativism and postmodernism [3. P. 15].

Speaking about the philosophy of the semiotic method, we should first trace the history of the philosophical foundations of semiotics.

You can start with the history of the ancient world. In the period of polytheism in ancient Egypt in the VIII century BC was written text, now known as the Memphis theological treatise. It speaks of "bringing together the creative word, thought and the world formed by these forces", which is a philosophical idea. There is an association with the concept of monism "all is one". Here the triad of sign-concept-object is already anticipated.

In ancient Greece there was opposition to the existing language in "nature" and "establishing" which was analyzed including in the Platonic dialogue "Cratylus" (IV century BC). In other words, it was discussed whether the sign was conventional or natural in nature. This treatise contains a reflection on how the sign and the image relate to the thing, and discusses the role of the sign and language in communication and knowledge.

The question of how adequately the name could reflect essence of the ever-changing world, is also considered in the dialogue "Cratylus". This question does not lose its relevance until now, as the Italian semiotic Umberto Eco at the turn of XX-XXI centuries again asks: how adequate is the structure created by our consciousness in relation to the changing reality? For epistemology this is a serious question, because if the sign distorts the information, can we know the truth $[4 ; 14]$.

In the mentioned dialogue it is said that we create signs in the conditions of the world changing and thus only to the extent of the understanding which can be erroneous. Therefore, signs cannot perfectly reflect the truth. If we compare these thoughts with the Christian doctrine of God the Son, Jesus Christ, Who is the perfect image of the Father, His perfect expression and Word, it becomes clear that the Gospel, on the contrary, provides a basis for the representation of the image and sign that can serve the knowledge of the truth. This assumption can be checked by further considering the attitude of the Orthodox Holy Fathers to the problem of the sign.

In the process of reasoning about only through sign language and you can understand the nature of things, Plato draws attention to the degree of similarity of the sign to the object, which subsequently served as the basis for allocation of such signs as iconic, that is, having similarity with the object that is on its way. In the above-mentioned dialogue, Plato argues that the best knowledge is the study of the thing itself, that is, 
the object. Based on this, we can already judge the correctness of the chosen name for her. The sign is not the only means of knowledge. At the same time, speaking about reality, the philosopher uses the expression "the truth of things" known in Church hymnography (involuntarily the quote from the troparion to St. Nicholas is remembered: "the truth of things").

The saints Cappadocians (IV century A.D.) found it necessary to include in the "love of kindness" the text of Origen, which they called: "On the syntactic originality of Scripture and the [imaginary] poverty of expressions". In this part of "love of kindness" we find the triad word (sound) - denoted (object) - meaning ("thing"), which anticipates the arisen more than a Millennium after their death, the idea of the semantic triangle of Frege-Ogden-Richards. It says: "He who distinguishes in the mind of articulate sound, denoted by and things, according to which the referent is used, it is not in confusion before solecismic, occurring in words" [5. P. 10-11].

As we can see, already in this period the Holy fathers pay attention to the problem of the correlation of meaning and word, that is, the designated and the sign, recognizing the imperfection of the latter.

Speaking about the semiotic aspect in the works of the Holy fathers of the early Byzantine period, it is important to turn to the studies of S.S. Averintsev, a philologist and historian of Christian culture, who studied the monuments of writing of this era, a significant part of which came from the pen of the Holy fathers. His work "Poetics of early Byzantine literature" was defended as a doctoral thesis in 1980. S.S. Averintsev also touched upon the semiotic aspect of this literature, that is, revealed the role of the sign in it [6. P. 126-127].

On the importance of the theory of the sign for this period, he writes the following: "Further, the theory of the sign, the aesthetics of the symbol, the philosophy of the name are also "eternal" tasks of knowledge, independent of confessional ideology. If the symbol can be argued that idealistic speculation and mystical contemplation are particularly interested in this category - although, of course, they are not alone - then the sign is a category of worldview neutral. However, in the specific conditions of the era this whole issue has become extremely popular because they were correlated with the religious and political life: the problem of interpretation of the Scriptures (for Christians, the Bible, and to the Gentiles - the other texts accepted as sacred), with difficulties when trying to articulate the "ineffable" mystical content, with the needs of the theory of cult, even with the need to comprehend the entire "visible" and it is the earthly reality of the state and the Church-hierarchical institutions as some of the "icons" of a different reality, invisible and transcendent. So is the case with semiotic and symbolological topics of the philosophy of the IV-VII centuries" [7. P. 47].

S.S. Averintsev points out that St. Basil the Great paid attention to the theme of the philosophy of name. A name is a kind of sign, so this question has to do with semiotics. Opposing the extremes of eunomianism, which claimed that even the essence of God can be expressed in the name completely, and agnosticism, archbishop of Cappadocian Caesarea argued that the name gives an adequate idea of some of the properties of a particular entity. This is possible thanks to the cognizable energies (actions) of this unknowable entity. Thus, St. Basil lays the foundation for the doctrine of the Divine energies of St. Gregory Palamas (XIV century). 
Sergey Sergeyevich writes that for the early Byzantine era the theme of the sign, symbol and name is Central. Note that he considers these concepts in the framework of one topic. The semiotic aspect in the theological works of the Holy fathers of Averin notes, mentioning the works of St. Augustine of Hippo, who considered in detail the concept of the sign, and the works of St. Basil. "The fact that Basil, a thinker, generally speaking, not too fond of symbolism, in a very unusual for the Christian Platonic measure skeptical about the allegorical interpretation of the Bible, could not pass by this problem, the more significant" [ ibid., P. 72-73].

Since the semiotic method exists within the framework of semiotics, we should pay attention to the fact that John Locke already spoke about this science as the most important sphere of knowledge in the XVII century. Briefly, we note that it was developed by Charles Pierce, major scientists in this field were also Lotman and Umberto Eco.

However, there are researchers who denying the universality of semiotic method and see flaws in the philosophical foundations of the semiotics. Doctor of philosophy E.A. Gorny writes: "Criticism of the semiotic method is at the same time a criticism of science, which is based on the principles of mechanism, positivism and the exclusion of the subject of knowledge from the sphere of knowledge itself" [8. P. 175].

"Semiotics is the creation and apologetic self-affirmation of the blind mind, detached from reality, unable to see it as it is, without any means, i.e. the mind in a state of ignorance.

Semiotics, ontologizing "binary oppositions" as a universal structure of cognition, is able to deal only with illusory, or relatively real, phenomena. It denies the existence of a deeper or higher reality... reality as it is. The semiotic mind, which has dominated Western culture for at least the last six centuries and acts as an almost universal "censorship of understanding", "is concerned with what is in fact unreal" [ ibid., P. 174].

These arguments are essentially a critique of structuralism. They are in tune with the statements of Plato and Umberto Eco. A sign is always a means of cognizing reality, and not the reality itself, which can be revealed to a person without the sign. In addition, the wrong attitude to the sign can give rise to a number of serious problems. Starting with an erroneous interpretation and unlimited semiosis, when one sign refers only to another sign, and not to the object of reality, and ending with the virtualization of human consciousness, as S. Khoruzhy says: "There are both acquisitions and dangerous sides. Expanding experience and abilities — but they are expanding by immersion in a diminished and separate, not fully realized and not fully formed reality, the scope of the minimum threshold of happening and energy. Hypertrophy of the "virtualist worldview" is a sign of "the energetic decline of man and the world - the decline is not quantitative, but qualitative: the decline of the form-building will and ability" [9. P. 350]. Thought of Khoruzhy, people with this attitude to the world closes in virtuality, taking responsibility and losing the ability to create.

\section{Semiotic Method in Science: Philology}

Let us pass from the philosophical foundations of the semiotic method to the consideration of its specific application in scientific research. Precedent and an example of the use of this approach are the work of the above-mentioned philologist S. Averintsev. 
Let us consider the methods of analysis of the text that Sergey Averintsev used when writing the Chapter "Literature" of the collection "Culture of Byzantium: IV — the first half of VII" and the monograph "Poetics of early Byzantine literature".

Within the framework of the semiotic methodology, such methods as functional and diffusion are used. The functional method is the definition of the role of a language unit in a language or text, and the diffusion method is the tracing of borrowings of certain language units.

At the very beginning of his analysis in the said collection Averintsev states: "the Paradox of early Byzantine literature can be understood in the context of a broader socio-historical and cultural-historical paradox". He considers the object of study in its dynamics.

The Professor describes the emergence and development of early Byzantine literature as diffusion: Christian authors borrow rhetorical techniques and images from ancient pagan authors, filling this form with new content, which in the modern context gives rise to a new cultural phenomenon .

When S.S. Averintsev reflects on the creation of St. Gregory the theologian "Oh, Exceeding all!..", he draws attention to the fact that the poet uses hexameter the oldest form of ancient verse, in which Homer wrote his works. At the same time, the scientist notes that there are no specific biblical motifs in the poem itself, which gave rise to the Western philologist of the XIX century to consider the poem the work of the pagan philosopher Proclus. Immediately note that S.S. Averintsev with such attribution of the text does not agree, indicating that the love of God and the desire of the soul to Him, which the archbishop of Constantinople writes, incompatible with the tradition of pagan hymnography. Thus, we have a clear example of cultural diffusion.

The functional method is also used by scientists. About the work of St. Roman sweet-singer in "the Poetics of early Byzantine literature", he writes: "And if the verses given in the narrative and appeal to the people, the refrain may assume the function of the cult call of God, and thereby put the story in the context of the continuing "conversations" with God, "anticipation of" him".

S.S. Averintsev also mentions St. Basil the Great. The Soviet philologist clearly indicates the function of the sermons of the Bishop of Cappadocian Caesarea: the purpose of the Holy father is to bring the Orthodox theological and moral teaching to the mind and heart of every listener, to encourage him to change his life in accordance with the gospel commandments. For him, "the word becomes an applied tool of effective persuasion, influence on the minds". As well as Yu.M. Lotman, S.S. Averintsev draws attention to the fact that for the reader unfamiliar with the context in which the work was created, that is, not seeing the relationship of the features of the text with the cultural norm existing at the time of the birth of the verse, it is more difficult to adequately interpret the text. This is the functional method.

S.S. Averintsev applies the functional method, referring areopagitica corps. He notes the General purpose of the metaphors of Nonnus and the author of "Areopagitic" to emphasize the inexpressiveness of the described reality. He cites the text from the above-mentioned source: "the Divine darkness is that unapproachable light in which, 
according to the Scripture, God dwells; the light is invisible because of excessive clarity... and into this darkness enters anyone who has been granted to know and contemplate God precisely through non-vision and non-cognition...". And then the scientist comments: "the Theologian has as little trust in each individual word to carry an adequate meaning, as the poet is not inclined to assign each individual metaphor to express an adequate image". In the text of the theologian there is "unimaginability, embedded in the human psyche contradiction, which is designed to "transform" this psyche". "...the 'super-task' of these words is not in utterance, but in expressive silence, in inspiring the reader with a sense of going beyond the word". Applying the functional method, the Professor describes the form of expression that was chosen when using the apophatic method to convey the theological content.

\section{The Semiotic Method in Theology}

Immediately we must say that in theology there is no such thing, but the problem of the sign, as was shown above, was considered by the holy fathers.

Theology as a science is "the practice of the assimilation by man of the systematization and presentation of eternal revealed truths, the church experience of faith and communion with God", as stated in the Orthodox Encyclopedia. We read there also: "The sacrament of the Incarnation makes possible not only any Christian symbolism and icon veneration, but also the possibility of a semantic and verbal description of God. Theology becomes the verbal icon of Christ”. Finally, St. Gregory Nazianzus called theology "the word about God". Since we are talking about words, it is clear that theology as an exposition of truths is possible due to the presence of one or another language as a system of signs. In this system, the word is denoted by one or more characters.

Therefore, it is legitimate to regard theology as semiosis. Moreover, the sign is primarily a word, the object is predominantly God, and the interpreter is every person who hears or reads this word.

Hermetic (or unlimited) semiosis is a process of "infinite interpretation of some characters through others, which dialectically turns into practical action (also a special kind of interpretation of the message received) and for which, in principle, no stable code exists". One sign means another, and so on to infinity. In the absence of any restrictions on this process, U. Eco estimated this phenomenon negatively. He wrote: "...I am against a cancerous tumor of excessive interpretation, which you just cannot be satisfied with and continue to look for other answers".

U. Eco considered the interpretation of the Holy Scriptures on the principle that the Old Testament is the shadow of the New, and the New is the image of the future state of humanity and the world as a vivid example of just such a process. From the point of view of Eco, sacred texts are less subject to over-interpretation, as there is an age-old tradition of their interpretation, based on indisputable authority. The writer gave different examples of superinterpretations in their own works. From here, Nosachev concludes that Eco "does not advocate a complete restriction of the author's rights to his text".

Most clearly the topicality of the theme of the sign for theology was manifested in the Palamite disputes of the XIV century and later in the debate about the name (ono- 
matodoxy). It must be said that for St. Gregory Palamas and representatives of the Hesychast tradition it was obvious that a person knows God not only through signs, but precisely through His uncreated energies. Without diminishing the role of the sign in the history of the Revelation of the Creator to the world, the Eastern holy fathers urged not to dwell on the knowledge of the objects of this world, from which we can conclude about the existence of the Almighty, but to ascend directly to meeting and uniting with Him through His energies directly, that is, without the mediation of the sign. At the same time, it is possible to say, however, that in this connection man himself reveals himself as a sign-image of God, having the common property of spirituality with Him, as the saint himself writes.

We see that the Orthodox tradition encourages a person to search for the true reality and (for example, in the concept of delusion) warns against a circuit in the virtual illusory world. The Monk Maxim the Confessor argued that the essence of sin in seeking goodness where it does not exist, and this is the essence of charms as spiritual selfdeception: it seems to a person that he has grace-giving gifts in the absence of them.

If we consider the concept of an image as a kind of sign, then we can say that Christianity speaks only about one sign that coincides with an object - this is the Son of God, which is God and the image of God at the same time. Khoruzhy speaks of man as Nexus, uniting all horizons of being, but in the full sense for a Christian, such Nexus is Christ, uniting in Himself Divine and created being, who is in the image of man and in the image of God.

\section{Methods}

The research is supposed to be conducted using the following methods: review of sources, analysis, synthesis, comparison.

\section{Results}

It was established that the term "semiotic method" is absent in Orthodox academic theology, and in secular science it is relatively young and is first encountered not earlier than the 60 s of the 20 th century. The term "sign" associated with the above term in the history of Christian theology was considered specifically only by St. Augustine who died in 430 A.D. In the Orthodox Encyclopedia in the article "Sign" there is only a link to the article "Symbol", which at the moment (2019) does not yet exist.

Two lines of attitude to the universality of the epistemological properties of the sign were identified. There is a tendency to assert the absolute cognitive properties of the sign, and there is a modern rational criticism based on the tradition of ancient and Christian thought.

The conditions of the effective application of the semiotic method and the avoidance of unlimited semiosis were determined: following the tradition of interpretation and the correlation of the language unit with the context.

It was found that in domestic science, the works of S.S. Averintsev were the first precedent of applying the semiotic method in the study of theological texts. 


\section{Summary}

Answering the questions posed at the beginning, one can say the following.

1. Consideration of the philosophical foundations of the semiotic method leads to the conclusion that, from the point of view of Orthodox theology, all signs arising in the created world are limited and cannot give a full knowledge of reality, but only some idea about it. Semiotics is not universal, as it was evident both for Plato and for E. Gorny. Thus, on this issue there is agreement of a number of Orthodox and nonOrthodox thinkers of different eras.

2. Analysis of the epistemological significance of the semiotic method confirms the assertion that within the framework of science there can be no talk of a perfect cognition of reality, this would contradict the principle of the continuity of cognition. From the point of view of theology, a person can find the maximum possible knowledge of reality only in Christ as an image of the sign of God the Father, and it is higher than the intellectual one.

3. We see that signs are used in all the main spheres of culture (philosophy, science and theology), find it means that the semiotic method can be used and can be called universal, but only within the framework of this culture itself. This can be compared with points on a segment: the segment itself is limited, but within it you can put an infinite number of points.

4. To avoid the danger of endless interpretation of some signs with the help of others and to learn something about reality itself, it is necessary to limit hermetic semiosis with the help of the tradition of interpretation of signs and analysis of the context of their application, as exemplified by the Sacred Tradition of Orthodoxy, Tradition as a criterion for interpreting and evaluating phenomena.

5. S.S. Averintsev contributed to the development of the practice of the semiotic method in Russian science. Without using this term, he considered the early Byzantine culture as a system of signs, in more detail - literature. The identification of the function of a language unit, literary reception in the context of a written monument, consideration of the dynamics of their origin, historical context, identification of cultural diffusion which characteristic for this approach serve a clearer perception of texts and a presentation of the realities of the era. In the Averintsev's works of, these techniques are demonstrated with the utmost clarity and visibility, and the results of their application are presented with logical coherence. The reader is naturally communicated by the author to the realization of the role of the mark in the subject under study.

6. The practical usefulness of the semiotic method can be considered the ability to bring the researcher as close as possible to the vision and understanding of the object of study. S.S. Averintsev, at that time a Soviet scientist, presented to the audience the reality of the era of early Byzantium in volume, vividly and in detail. Provided that we do not have the opportunity to view events and realities as past objects one and a half thousand years ago, the signs we study - the texts and artifacts of that era describe it eloquently and make it possible to more clearly understand modern realities in contrast and comparison.

For science, all of the above means that the semiotic method can be applied. But with one caveat: it is applicable in any sphere, and in this sense it is universal, but it is limited due to the limited nature of the sign itself, which always invites to push off from it and meet with what it really is, with Being and Life. Theology can give some guide- 
lines for science when discussing its philosophical foundations. Let one of them be the statement of St. Gregory Palamas: «In general, common for all believers in Christ have supermind knowledge; and the goal of true faith is achieved by fulfilling the commandments, leading to the knowledge of God, of course, not through merely created things, but from the uncreated light, which is the glory of God, the Lord Christ, and all those who have been rewarded with a Christ-like inheritance: "for Christ will come in the glory of the Father, in the glory of their Father, Christ, and the righteous will Shine as the sun" (MT.13:43, 16:27) and they shall be light, and they shall see light, joyful and all-Holy, a sight accessible only to a pure heart".

Article history:

Received: 1.06 .2019

Accepted: 15.09.2019

\title{
История статьи:
}

Дата поступления: 1.06.2019

Дата приема в печать: 15.09.2019

\section{References}

1. Zherebilo, T.V. (2010). Dictionary of linguistic terms. Nazran.

2. Lotman, Yu.M. (1964). Lectures on structural poetics In Scientific notes of Tartu State University. Works on sign systems; Vol. 160. Tartu.

3. Taysina, E.A. (2014). Philosophical questions of semiotics. St. Petersburg.

4. Nosachev, P.G. (2009). The limits of text interpretation as a key problem of the Umberto Eco concept [dissertation]. Moscow.

5. Mikhailov, P.B. (2011). The exegetics of scripture. Cappadocian Fathers. Moscow.

6. Averintsev, S.S. (2000). Alexy Studit In Orthodox Encyclopedia under the general. Patriarch of Moscow and All Russia Alexy II (ed.). Moscow: Church scientific center "Orthodox encyclical". pp. 126-127.

7. Prayer books and canons for every week of the week and every request of the soul (2004). Orthodox Publishing Center "Verb". Moscow.

8. Gorny, E.A. (1996). What is semiotics? In Raduga. Tallinn. pp. 168-175.

9. Khoruzhiy, S.S. (2000). About the old and the new. St. Petersburg: Aletheia.

Научная статья

DOI: $10.22363 / 2313-2299-2019-10-3-610-621$

\section{Семиотический метод познания реальности: границы применимости}

\author{
П.А. Кузьмин \\ Московская духовная академия \\ 141300, Московская область, г. Сергиев Посад, территория Лавра, Академия
}

\begin{abstract}
Аннотация. В данной статье рассматриваются степень и полезность применимости семиотического метода в науке, философии и академической теологии. В статье рассмотрена философия семиотического метода и его связь с православным богословием. Представлен и исследован конкретный случай применения семиотического метода в отечественной науке в трудах С.С. Аверинцева для изучения богословских текстов. Делается вывод о том, что экстенсиональная универсальность семиотического метода во всех сферах знания и его ограничения в способности адекватно отражать реальность.
\end{abstract}

Ключевые слова: семиотический метод, семиотика, знак, реальность, теология 


\section{Библиографический список}

1. Жеребило Т.В. Словарь лингвистических терминов. Назрань, 2010.

2. Лотман Ю.М. Лекции по структуральной поэтике // Ученые записки Тартуского государственного университета. Труды по знаковым системам. Вып. 160. Тарту: 1964.

3. Тайсина Э.А. Философские вопросы семиотики. СПб., 2014.

4. Носачев П.Г. Пределы интерпретации текста как ключевая проблема концепции Умберто Еко: дисс. ... канд. филос. наук. М., 2009.

5. Михайлов П.Б. Экзегетика Священного Писания. Каппадокийские отцы: учебное пособие. M., 2011.

6. Аверинцев С.С. Алексий Студит // Православная энциклопедия / под общ. ред. Патриарха Московского и всея Руси Алексия II. М.: Церковно-науч. центр «Православная энцикл.», 2000. С. $126-127$.

7. Молитвослов и каноны на каждый день седмицы и всякое прошение души. М.: Православный издательский центр «Глагол», 2004.

8. Горный Е.А. Что такое семиотика? Таллинн: Радуга, 1996. С. 168-175.

9. Хоружий С.С. О старом и новом. СПб.: Алетейя, 2000.

\section{Для цитирования:}

Кузьмин П.А. Семиотический метод познания реальности: границы применимости // Вестник Российского университета дружбы народов. Серия: Теория языка. Семиотика. Семантика. 2019. T. 10. № 3. C. 610 -621. doi: 10.22363/2313-2299-2019-10-3-610-621.

\section{For citation:}

Kuzmin, P.A. (2019). The Semiotic Method of Cognition of Reality: Limits of Applicability. RUDN Journal of Language Studies, Semiotics and Semantics, 10 (3), 610 - 621. doi: 10.22363/2313-22992019-10-3-610-621.

\section{Сведения об авторе:}

Кузьмин Платон Алексеевич, магистр богословия, аспирант Московской духовной академии, чтец; e-mail: platonkuzmin@gmail.com

\section{Information about the author:}

Platon A. Kuzmin, Master of Theology, graduate student of the Moscow Theological Academy, lector; e-mail: platonkuzmin@gmail.com 